\title{
B-lactams serum concentrations in critically ill cirrhotic patients: a matched-control study
}

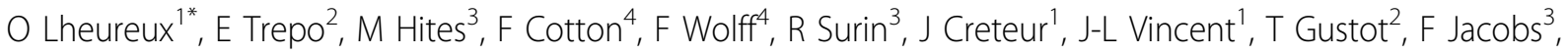 \\ FS Taccone ${ }^{1}$
}

From ESICM LIVES 2015

Berlin, Germany. 3-7 October 2015

\section{Introduction}

Few data are available on the pharmacokinetics (PKs) of b-lactams in critically ill cirrhotic patients.

\section{Objectives}

The objective of this study was to evaluate whether cirrhosis was associated with alterations in b-lactam concentrations when compared to other critically ill patients, and to identify the principal risk factors for inadequate concentrations in these patients.

\section{Methods}

We reviewed data from critically ill cirrhotic patients and matched controls in whom routine therapeutic drug monitoring (TDM) of broad-spectrum $\beta$-lactam antibiotics (ceftazidime or cefepime, CEF; piperacillin/tazobactam; TZP; meropenem, MEM) was performed. Serum drug concentrations were measured twice during the elimination phase by high-performance liquid chromatography (HPLC-UV). Antibiotic PKs were calculated using a one-compartment model. We considered therapy was adequate when serum drug concentrations were between 4 and 8 times the minimal inhibitory concentration (MIC) of Pseudomonas aeruginosa during optimal periods of time for each drug $(\geq 70 \%$ for $\mathrm{CEF} ; \geq 50 \%$ for TZP; $\geq 40 \%$ for MEM).

\section{Results}

We studied 42 cirrhotic patients ( 4 for CEF, 16 for TZP and 22 for MEM) and 42 matched controls. Drug dosing was similar in the two groups. The PK analysis showed a lower volume of distribution (Vd) of MEM $(\mathrm{p}=0.05)$ and a lower antibiotic clearance (CL) of TZP $(\mathrm{p}=0.009)$ in patients with cirrhosis when compared to non-cirrhotic

\footnotetext{
${ }^{1}$ ULB, Intensive Care, Brussels, Belgium
}

Full list of author information is available at the end of the article patients. More cirrhotic patients have excessive serum b-lactam concentration ( $\mathrm{p}=0.015)$, in particular for TZP.

\section{Conclusions}

Standard regimens of $\beta$-lactam resulted in excessive serum concentration in two-third of the patients in the cirrhotic cohort. These findings are mainly marked in cirrhotic patients treated by TZP, probably because of reduced drug CL.

\section{Authors' details}

${ }^{1}$ ULB, Intensive Care, Brussels, Belgium. ${ }^{2} U L B$, Gastroenterology, Brussels, Belgium. ${ }^{3} U L B$, Infectious Disease, Brussels, Belgium. ${ }^{4} U L B$, Clinical Chemistry, Brussels, Belgium.

Published: 1 October 2015

doi:10.1186/2197-425X-3-S1-A401

Cite this article as: Lheureux et al:: B-lactams serum concentrations in critically ill cirrhotic patients: a matched-control study. Intensive Care Medicine Experimental 2015 3(Suppl 1):A401.

Submit your manuscript to a SpringerOpen ${ }^{\odot}$ journal and benefit from:

- Convenient online submission

- Rigorous peer review

- Immediate publication on acceptance

- Open access: articles freely available online

- High visibility within the field

Retaining the copyright to your article

Submit your next manuscript at $>$ springeropen.com

\section{SpringerOpen $^{\circ}$}

(C) 2015 Lheureux et al.; This is an Open Access article distributed under the terms of the Creative Commons Attribution License (http:// creativecommons.org/licenses/by/4.0), which permits unrestricted use, distribution, and reproduction in any medium, provided the original work is properly cited. 